\title{
INKLUZÍV PEDAGÓGIA a Pázmány Péter Katolikus egyetem BölCSÉSZET- ÉS TÁRSADALOMTUDOMÁNYI KARÁN
}

\section{GOMBOCZ ORSOLYA}

\author{
a Pázmány Péter Katolikus Egyetem Bölcsészet- és Társadalomtudományi Karának \\ egyetemi docense \\ gombocz@mail.hupe.hu
}

\begin{abstract}
A szerzö írásában bemutatja, hogy a Pázmány Péter Katolikus Egyetem Bölcsészet- és Társadalomtudományi Kar Tanárképzö Intézete milyen lehetöségeket kínál hallgatóinak, hogy megismerkedjenek a multikulturalitás jelenségével, ismereteket szerezzenek az integrációról, felzárkóztatásról. Az Intézet törekvése, hogy az inkluzív pedagógiáról való tudás ne pusztán az elöadások, szemináriumok klasszikus keretei közt alakuljon ki, hanem személyes tapasztalatot, élményt is szerezzen a hallgató.
\end{abstract}

Közismert tény, hogy a pedagógusnak mindig is számtalan kihívásnak kellett megfelelnie, munkája szerteágazó voltához nem fér kétség. Napjaink társadalmának alakulása ezt a sokrétüséget mind inkább kiterjeszti, és erre a tanárképzésnek is meg kell adnia a választ.

A tanárképzés kétszintűvé tétele egyetemünknek sem pusztán az átalakítással járó munkát, hanem a képzés megújításának-megújulásának a lehetőségét is jelentette. A központi követelményeknek való megfelelés kényszerén túl egyetemünk katolikus volta is azt az elvárást támasztotta, hogy a tanárképzés programja - sok egyéb ismeret és kompetencia mellett - magában foglalja az inkluzív pedagógia kérdéskörét is. Tanszékünk személyi állománya felkészült erre a feladatra. Tantárgyaink átfogó tematikai elemzésével közösen megkerestük azokat a tananyag-egységeket, amelyek különösen alkalmasak a hallgatók szemléletének hatékony formálására, az inkluzív gondolkodásmód és a személyi pedagógiai eszköztár fejlesztésére.

A tanári mesterképzési szak programjában külön, kötelező tanegységként ugyan nem szerepel a multikulturális nevelés, hátrányos helyzet, felzárkóztatás, integráció, illetve az inklúzió kérdése, de a tantárgyi programok közül több is foglalkozik ezekkel a kérdésekkel: így például A „Neveléselmélet” címü előadás, és különösen a hozzá kapcsolódó „A nevelés gyakorlati feladatai” elnevezésü szeminárium eltérő hangsúllyal ugyan, de mindegyik kérdéssel foglalkozik. Ugyanezt teszi az „Oktatáselmélet” előadás is, természetesen az oktatás nézőpontjából megközelítve a kérdést. 
Tanárképzésünk a kétszintűvé válással párhuzamosan komoly változást élt meg annak köszönhetően, hogy beindítottuk a tanári mesterszakot pedagógiatanár második szakterületi modulként. Ennek programja több olyan szemináriumot is tartalmaz, melynek kimondott feladata az ebbe a kérdéskörbe tartozó feladatokra való felkészítés. Témánk szempontjából a két legfontosabbat: Az „Inkluzív pedagógia” szemináriumát, illetve a „,Multikulturális nevelést” is a 2011-2012-es akadémiai év tavaszi szemeszterében hirdettük meg elöször.

$\mathrm{Az}$ „Inkluzív pedagógia” szemináriumi formában, heti két órában, két kredit értékben szerepel a programban. A tárgy célja, hogy a hallgatók befogadó, inkluzív pedagógiai magatartást sajátítsanak el. Legyenek érzékenyek az esély, a speciális szükséglet és a fogyatékkal élés problematikájára, toleranciával forduljanak a kevesebb eséllyel rendelkező társadalmi csoportok és konkrét személyek felé. Legyenek tisztában a pedagógiai tevékenység esélynövelö vagy esélycsökkentő tényezőivel. Legyenek képesek elemezni azokat a társadalmi, kulturális, valamint pszichológiai tényezőket, amelyek esélycsökkentő, kirekesztő hatásúak a gyermekek, fiatalok életében. Ismerjék az integráció lehetséges formáit, sajátosságait, követelményeit, és az inkluzív pedagógia megvalósításának konkrét lépéseit. Legyenek képesek a tanulók személyiségét fejleszteni, inkluzív szellemben tervezni a pedagógiai munkát, és együttműködni a fejlesztés érdekében a szakma, illetve a társadalom többi szereplöjével. A tárgy egyszerre érinti az inkluzivitás társadalmi dimenzióit, a speciális szükséglet, illetve a hátrányos helyzet (kevesebb esély) jelenségeit és az azokra adott pedagógiai válaszokat, miközben a hallgatók nézeteinek feltárását, alakulását is segíti. A tárgy témái:

1. A befogadó társadalom keresztényi gyökerü eszménye, és az esély problémája a nyugati, polgári társadalmakban.

2. A hátrányos helyzet értelmezései, saját nézeteink különböző társadalmi csoportokkal kapcsolatban.

3. A kevesebb eséllyel rendelkező csoportok: speciális szükségletek, hátrányos helyzet, fogyatékkal élők, kulturális különbségek stb.

4. A pedagógia és az iskolarendszer esélycsökkentő, kirekesztő tényezői.

5. A kirekesztéssel szemben: az integráció formái.

6. Az inkluzív szemléletmód a pedagógiában.

7. Gyakorlati megvalósítások az inkluzivitás terén.

8. Utak, módszerek, nehézségek az inkluzív pedagógiában.

9. Interkulturális nevelés.

A szemináriumot első félévében az akkreditált képzés leírásának megfelelően az alábbi tematikával és követelménnyel hirdettük meg (a témánk szempontjából releváns részek):

1. Alapfogalmak. Az inkluzív oktatás. Az inklúzió faktorai. Az inklúzió feltételei és tényezői. Szegregáció, integráció-történeti vonatkozások. 
2. A fogyatékos személyek egyenlő oktatási esélyeivel kapcsolatos nemzetközi tevékenység.

3. Az integrált nevelés megvalósításának nemzetközi trendjei.

4. A különtámogatásban részesülő sajátos nevelési igények kategóriái Magyarországon. Bevezetés az integrált oktatást meghatározó törvényi szabályozásba.

5. Az integrációt elősegítő törvények gyakorlati megvalósulása. Az integráció/inklúzió helyzete Magyarországon.

6. Iskola és inklúzió. Az iskola fizikai feltételeinek kialakítása, az iskolavezetés és a tantestület munkájának fejlesztése.

7. Az inklúzió mint a változtatás hajtóereje. Tantárgyközi együttmüködés. A pedagógiai hozzáadott érték.

8. Differenciált tanulásszervezés. A nem-verbális intelligencia mozgósítása a tanulási folyamatban. Vak gyermek a többségi osztályban.

9. A pedagógus személyes fejlődése és az inklúzió.

10. Az SNI tanulók társas helyzete.

11. A szülő és a sajátos nevelési igényű gyermek.

12. Összefoglalás és értékelés.

Követelmények: A hallgatók a választott témában beszámolót tartanak, illetve csoportokban az egyes témákhoz kapcsolódóan projekteket dolgoznak ki a szemináriumvezetö útmutatásai és intézménylátogatások alapján, majd ezeket a szemeszter végén bemutatják. Ezekre a projektekre kapnak gyakorlati jegyet a hallgatók.

A ,Multikulturális nevelés” szintén szemináriumi óra, két kredit értékkel. A tárgy célja: a multikulturális pedagógia értelmezésének, céljainak és jellemzőinek, valamint módszereinek ismertetése és gyakorlati alkalmazása. A tanegység keretében a hallgatók megismerkedhetnek a több kultúrára épülő személyiségfejlesztés módszereivel, melyben a diákok előnyként élik meg az eltérő kulturális hátteret, így fejlődik a kooperációs és empatikus kompetenciájuk. A tárgy tematikája:

1. Kulturális sokszínüség, a kultúra főbb elemei (multikultúra, globalizáció stb.).

2. A nemi különbségek szocializációs jellemzői, a különböző életkorú emberek elfogadása (például: fiúk-lányok eltérő fejlődési üteme, szabálykövetési stratégiák).

3. A társadalmi és képességbeli különbségek feldolgozása és iskolai kezelésének módszerei (szegények-gazdagok, tehetségesek és leszakadók, az esélyegyenlőség, sajátos nevelési igényü diákok problémái stb.).

4. Az etnikai, nemzetiségi különbségek értelmezése (például elöítélet, diszkrimináció).

5. A nyelvi hátrány és nyelvi szocializáció (például a nonverbális kommunikáció jelentősége). 
6. Vallási különbségek az egyházhoz tartozók normái (a vallásos nevelés jellemzői stb.).

7. A kultúraérzékeny iskola jellemzői, a differenciálás és az adaptív nevelés formái és jellemzői.

Ezeket a szemináriumokat természetesen minden hallgatónk felveheti, így a nem pedagógia szakos hallgatók jelenléte is megfigyelhető óráinkon. A félév során mi is, mint sok más tanárképző egyetem oktatói, igyekszünk hallgatóinkat a gyakorlatba is bevezetni, ennek érdekében szemináriumi keretek közt intézménylátogatásra megyünk velük.

Az inkluzív nevelésre való felkészítésnek más - a téma iránt érdeklődők közül talán többeknek érdekesebb - megoldásai is vannak karunkon, nem csak a szorosan vett tantervi tanegységek. Katolikus egyetem lévén nagy hangsúlyt fektetünk arra, hogy hallgatóink az egyetem szellemiségének megfelelő képzésben részesüljenek. Ne csak tanuljanak az inkluzív nevelésröl, ne csak intézményt látogassanak, hanem lehetőség szerint saját tevékenység által átélhetővé is váljon ennek a nevelői magatartásnak a jelentősége.

Hosszú múltra tekint vissza az a kötelezővé ugyan nem tehető, de nagy népszerüségnek örvendő gyakorlatunk, hogy hallgatóink itthon és határon túli magyarlakta településeken is folytatnak nyári munkát. A gondolat annak kapcsán fogalmazódott meg, hogy hallgatóinknak - még a hagyományos képzés keretein belül nyári gyakorlatot kellett abszolválniuk, szigorú feltételek és ellenőrzés mellett. Sokan igazi kihívást láttak a feladatban, és szinte egymással versenyezve keresték a nehezebbnél nehezebb nevelöi terepeket. Feladatunknak tartottuk, hogy a hallgatók érdeklődésének megfelelő és igazi értéket teremtő feladatokat kínáljunk nekik, ahol úgy érezhetik, fontos, amit csinálnak. Határon belül és kívül szép példáit láttuk a hallgatók számára meghatározó élményt nyújtó gyakorlatoknak. Ezért fontosnak tartottuk, hogy a kétszintü tanárképzésben is folytatódjon a gyakorlatnak ilyen módon történő megszervezése. Az ország nehéz sorsa arra hívta fel a figyelmünket, hogy a nyári táboroztatás mellett nagy szükség lenne hallgatóink segitö, felzárkóztató, adott esetben szociális munkájára a tanév közben is. Igyekszünk minél több intézményt megkeresni, kapcsolatot építeni, hogy hallgatóink hasznossá tehessék magukat. Figyelmünk elsősorban a katolikus intézményekre irányul, de nyitottak vagyunk más kezdeményezésekre is. Sajnos sok program, mellyel megkeresnek bennünket anyagi vagy egyéb okok miatt nem válik valóra, vagy menet közben megszünik. További nehézséget jelent, hogy a katolikus egyetem hallgatói is egyre inkább rákényszerülnek arra, hogy egyetemi tanulmányaik mellett dolgozzanak, és ez erősen befolyásolja egyéb tevékenységüket. Ennek ellenére sokakat vonz az egyetem lelkésze által a határon túli gyerekek számára szervezett táboroztatás, illetve a tanév közbeni vendégül látásuk, amelynek során az inkluzív pedagógia gyakorlatát testközelből ismerhetik meg. 
Több szemeszteren keresztül hallgatóink részvételével támogattuk a piliscsabai Tanoda müködését. 2004 öszén a piliscsabai roma közösség tagjai életre hívták a Tanodát, azzal a céllal, hogy gyermekeik délutánonként szervezett keretek közt töltsék el idejüket, lehetőségük legyen együtt tanulni, kikapcsolódni. Ebbe a munkába kapcsolódott be az egyetem Tanárképző Intézete. Tanácsadással és a hallgatóinknak szervezett gyakorlattal segítettük a Tanodában folyó munkát. Hallgatóinknak jó lehetőség volt kipróbálni magukat: saját szakpárjuk tanításán túl gyakorolhatták a szabadidő szervezést, a neveltekkel, szülőkkel való kapcsolatfelvételt, a nevelői magatartást, és persze sok élménnyel is gazdagodhattak. Az ott folyó sokszor nehéz, de szép munkáról Polákovits Nándor kollégánk számolt be a Mester és tanitvány címü folyóirat 14. számában.

\section{Irodalom}

Polákovits Nándor (2007): A valóság egy másik szelete - A PPKE hallgatói a piliscsabai

Tanodában. Mester és Tanítvány, 14. sz. 71-76.

PPKE BTK tanári mesterképzési szak tantárgyleirások részletei. Kézirat. 